\title{
O przedmiocie i zadaniach translatoryki raz jeszcze
}

\author{
The subject and goals of translatorics once again
}

\section{Franciszek GRUCZA}

Społeczna Akademia Nauk/ University of Social Sciences

E-mail: fkgrucza@uw.edu.pl,

\begin{abstract}
The aim of this paper is to present current status of translatorics, including its subject and main goals. The paper is a review of my past views on translatorics, published in numerous papers and monographs since 1973, in comparison to my current position, based on long-term research. The term 'translatorics' was mentioned first time by myself in the conference monograph, published in 1981. Since then, my scientific work was focused and aimed to study the subject, goals, characteristics, and important discrepancies between the discipline, which I called 'translatorics' and other, apparently, similar ones: 'traductology', 'translation studies', 'translatology', 'translation' and 'the theory of translation' respectively.
\end{abstract}

Keywords: linguistics, translatorics, translation studies, traductology, translatology, translation

\section{1.}

Rozprawa, w ramach której nazwę „translatoryka” wymieniłem po raz pierwszy, ukazała się w 1981 roku w ramach zredagowanego przeze mnie tomu materiałów IV. Sympozjum Instytutu Lingwistyki Stosowanej Uniwersytetu Warszawskiego. Sympozjum to odbyło się w podwarszawskiej Jachrance w dniach od 3 do 5 listopada 1976. Tom, o którym mowa, ukazał się pt. Glottodydaktyka a translatoryka, a moja omawiana rozprawa pt. Zagadnienia translatory $k i^{1}$. Jej włoskojęzyczna wersja ukazała się pt. Problemi di Translatorica, w tomie przygotowanym do druku przez Lorenzo Costantino i opublikowanym w 2009 roku pt. Teorie della traduzione in Polonia przez wydawnictwo Sette Sita (Włochy). Z zestawienia daty ukazania się rzeczonego tomu oraz odbycia tamtego Sympozjum wynika, że pierwotną wersję omawianej rozprawy napisałem pięć lat przed ukazaniem się tego tomu.

Ponieważ z naturalnych powodów stale maleje zbiór czytelników, którzy żyli i tworzyli prace naukowe w czasach, w których napisałem i opublikowałem ową rozprawę, i zarazem stale powiększa się zbiór czytelników, którzy nie znają realiów tamtych czasów, ale wiedzą natomiast, jak prędko (jeśli ma się na to zabezpieczone finanse) można dziś opublikować drukiem dowolny tekstu, dopowiem, że ów pięcioletni dystans czasowy pomiędzy napisaniem pierwotnej wersji tej rozprawy i jej opublikowaniem nie powstał dlatego, bo tyle czasu potrzebowałem na przygotowa-

\footnotetext{
${ }^{1}$ F. Grucza $(1976)=$ F. Grucza $(2017 a)$.
} 
nie jej wersji ostatecznej. Większość tego czasu zajęła realizacja obowiązującej wówczas, a dziś mało komu znanej, procedury wydawniczej.

By móc wówczas opublikować jakikolwiek tekst, także naukowy, trzeba było najpierw przygotować jego projekt, następnie oficjalnie zgłosić zamiar publikacji opisanego dzieła i poczekać na jego zaopiniowanie (zarówno merytoryczne, jak i cenzorskie) i włączenie go, oczywiście w przypadku jego pozytywnego zaopiniowania, do tzw. planu wydawniczego odpowiedniej katedry lub odpowiedniego instytutu, wydziału oraz uniwersyteckiego wydawnictwa, i wreszcie zatwierdzenia każdego z tych planów. Również o wiele więcej czasu niż dziś zajmowało tzw. drukarskie złożenie tekstu przeznaczonego do publikacji, jego wydrukowanie, wykonanie dwóch korekt jego wydruków, naniesienie poprawek na płyty drukarskie itd. Czasochłonne było też pocztowe przesyłanie wydruków tekstów autorom do korekty. Internetu nie było wówczas jeszcze nawet na poziomie idei. Czasem cały proces publikowania odrębnego tomu trwał krócej niż trzy lata, ale bywało też, że trwał on dłużej niż pięć lat.

\section{2.}

Na treść wymienionej rozprawy złożyły się rezultaty moich rozważań, po pierwsze, nad zagadnieniami, których systematyczne uprawianie zaliczyłem w niej do podstawowych (prymarnych) poznawczych zadań dziedziny wyróżnionej za pomocą nazwy „translatoryka”, oraz, po drugie, które stanęły przede mną w momencie postawienia pytania, pod jakimi warunkami można zasadnie już istniejącą lub dopiero tworzoną akademicką dziedzinę pracy poznawczej i/lub edukacyjnej uznać za należycie ufundowaną (meta)naukowo. Rozważaniem tych zagadnień w sposób systematyczny zająłem się zaledwie kilka lat wcześniej, dokładnie w 1973 roku - dość nagle i od razu w sposób bardzo intensywny, ale nie z powodu jakiegoś gwałtownego pojawienia się w moim umyśle potrzeby zajęcia się poznawaniem tego, co tradycyjnie wyróżnia się za pomocą takich wyrażeń jak „tłumaczenie” czy „,przekład”. Niczego takiego nigdy nie doznałem - zapewne dlatego, że nigdy nie zajmowałem się profesjonalnie praktycznym tłumaczeniem jakichkolwiek tekstów.

Powodem mojego nagłego skupienia się wówczas na tych rozważaniach była pewnego rodzaju ,zawodowa konieczność”, która pojawiła się, gdy wiosną 1973 roku w konsekwencji zupełnie nieoczekiwanej decyzji ówczesnych władz Uniwersytetu Warszawskiego zostałem, jako dyrektor Instytutu Lingwistyki Stosowanej tegoż Uniwersytetu, zobowiązany do uruchomienia z początkiem następnego roku akademickiego studiów mających na celu kształcenie tłumaczy. Zobowiązanie to nazwałem nieoczekiwanym, ponieważ wcześniej te same władze Uniwersytetu Warszawskiego były przeciwne uruchamianiu w ramach wspomnianego Instytutu jakiegokolwiek kształcenia tłumaczy. Dodam, że zmiana ich stanowiska w tej sprawie nie dokonała się wskutek jakiegoś namysłu nad wcześniej wysuwanymi przeze mnie argumentami na rzecz uruchomienia tego rodzaju studiów, lecz w konsekwencji zdecydowanie krytycznych wypowiedzi ówczesnego polskiego premiera na temat stanu przygotowania tłumaczy obsługujących go w czasie oficjalnej wizyty w Szwecji na początku 1973 roku. Na pytanie, kto odpowiada za ich wykształcenie, odpo- 
wiedziano mu zgodnie $\mathrm{z}$ prawdą, że nikt, bo wówczas nie było w Polsce żadnego uniwersyteckiego instytutu zajmującego się tym kształceniem jako swym głównym zadaniem edukacyjnym.

To w konsekwencji tego, skądinąd zupełnie przypadkowego, zdarzenia kierowany (a właściwie dopiero tworzony) przeze mnie Instytut Lingwistyki Stosowanej UW stał się nagle - z dziś na jutro - pierwszym polskim uniwersyteckim instytutem oficjalnie zobowiązanym i tym samym też oficjalnie uprawnionym, do uruchomienia i prowadzenia (akademickiego) kształcenia tłumaczy, dokładniej: uniwersyteckich studiów mających na celu akademickie kształcenie tego rodzaju specjalistów ${ }^{2}$. Dodam, że aż do 1990 roku Instytut ten był jedyną polską instytucją uniwersytecką oficjalnie kształcącą thumaczy i też jedynym polskim instytutem uniwersyteckim, w ramach którego translatoryką zajmowano się jako pewną dziedziną nauki wyraźnie wyróżnioną nie tylko nominalnie, lecz także instytucjonalnie - w ramach odrębnego zakładu. Ponadto pod koniec tego okresu udało mi się doprowadzić do zmiany kategorialnego statusu zarówno translatoryki, jak i kształcenia tłumaczy - dziedzina ta została wówczas stosowną decyzją ministerialną wyłączona $\mathrm{z}$ zakresu filologii i włączona w obręb lingwistyki stosowanej - efekt: absolwenci tych studiów otrzymywali wówczas dyplomy z nagłówkiem „magister lingwistyki stosowanej”.

\section{3.}

Zarysowana historia implikuje jednakże ,tak naprawdę" tylko odpowiedź na pytanie, co spowodowało, że w 1973 roku nagle podjąłem prace mające na celu jak najszybsze uruchomienie $w$ ramach kierowanego przeze mnie Instytut działalności nazywanej ,kształceniem tłumaczy”. Natomiast nie wyjaśnia ona przyczyny mojego zajęcia się od razu niezwykle intensywnie nie tylko rozważaniem kwestii dotyczących naukowych podstaw (programów) kształcenia tłumaczy oraz naukową analizą kwestii dotyczących translacji, lecz zarazem także (meta)naukowym konstytuowaniem akademickiej dziedziny, którą nazwałem translatoryką.

W każdym razie: wymienione wyżej oficjalne życzenie uruchomienia w ramach Instytutu Lingwistyki Stosowanej systematycznego kształcenia tłumaczy nie zobowiązywało mnie wprost do zajęcia się którymkolwiek z tych zadań. Przygotowując program owego kształcenia, nie musiałem (sit venia verbo) zawracać sobie głowy żadnymi naukowymi rozważaniami. Mogłem je ,zaprogramować”, i faktycznie „zaprogramowałem" je w taki sam sposób, w jaki zwykła to wówczas czynić (i przeważnie nadal czyni) zdecydowana większość podmiotów programujących jakiekolwiek wyższe (w tym uniwersyteckie) kształcenie specjalistów - czyli, w moim przypadku, na podstawie stosownej filologicznej tradycji oraz odnośnego praktycznego doświadczenia tłumaczy.

Zobowiązanym do intensywnego zajęcia się możliwie jak najprędzej naukowym rozwiązywaniem wymienionych zagadnień poczułem się z kilku innych - ściśle powiązanych ze sobą - przyczyn. Pierwszą i zarazem najważniejszą z nich stanowiło moje już wówczas mocno ugruntowane przekonanie, że podmioty zajmujące się

\footnotetext{
${ }^{2}$ Zob. F. Grucza (2017e).
} 
realizacją jakiegokolwiek wyższego kształcenia w obrębie jakiegokolwiek uniwersytetu, a w szczególności podmioty odpowiedzialne za programy tego kształcenia, mają zawodowy obowiązek systematycznego konfrontowania programów realizowanego kształcenia ze stającą, że tak powiem, do ich dyspozycji (już zgromadzoną) relewantną wiedzą o pracy, którą mają w przyszłości wykonywać kształceni przez nich specjaliści; że podmioty te mają obowiązek systematycznie przekształcać programy realizowanego kształcenia w programy możliwie dogłębnie ufundowane naukowo; że opatrywanie dowolnego uniwersyteckiego kształcenia jakichkolwiek specjalistów atrybutem ,naukowe” można uznać za zasadne tylko o tyle, o ile jego programy zostały w sposób naukowy ,wyprowadzone” z naukowej wiedzy o kształconych specjalistach, w szczególności z wiedzy o ich specjalistycznych aktywnościach (o konstytutywnych rodzajach ich specjalistycznej pracy) oraz o ich specyficznych właściwościach - z wiedzy pozyskanej w zgodzie z wymogami poznawczej pracy naukowej, czyli w skrócie: z odpowiedniej naukowej wiedzy specjalistycznej. Drugą z tych przyczyn stanowiło przekonanie, iż podmioty dowolnego wyższego kształcenia jeszcze nie będące w stanie naukowo ufundować programów realizowanego lub projektowanego przez nie kształcenia z braku odpowiedniej wiedzy specjalistycznej, mają obowiązek zadbać o to, by jak najszybciej rozpocząć prace naukowe mające na celu wypełnienie tej kognitywnej luki, a przynajmniej zmniejszenie jej wymiarów.

Do przekonań tych doszedłem kilka lat wcześniej w wyniku rozważań nad pytaniem o warunki, jakie musi spełniać kształcenie nauczycieli języków obcych pretendujące do miana kształcenia sensu stricte akademickiego, i co należy zrobić, by warunki te mogły zostać spełnione. Przygotowanie programu zleconego mi kształcenia tłumaczy poprzedziłem oglądem i oceną stojącej wówczas do dyspozycji odnośnej literatury fachowej i stanu przedstawionej za jej pomocą wiedzy. W rezultacie tego ,przeglądu” stwierdziłem niemal zupełny brak naukowej wiedzy, na podstawie której można by stworzyć prawdziwie akademickie programy tegoż kształcenia, ponieważ:

(a) badania (z)realizowane do tego czasu pod szyldami typu ,teoria thumaczenia" dotyczyły wyłącznie, a w każdym razie głównie, relacji pomiędzy oryginałami i translatami (prze)tłumaczonych tekstów, a nie specjalistycznych właściwości i/lub aktywności tłumaczy;

(b) stojąca wówczas do dyspozycji wiedza o tłumaczach była w zdecydowanej większości wiedzą ,wyprowadzoną" z praktycznych doświadczeń tłumaczy, a nie z odnośnych badań naukowych;

(c) w dodatku była to wiedza pozyskana niemal wyłącznie $\mathrm{z}$ doświadczeń tłumaczy różnego rodzaju tekstów literackich;

(d) analizy realizowane wówczas pod tego rodzaju szyldami jak teoria tłumaczenia dotyczyły głównie, jeśli nie wyłącznie, tłumaczonych tekstów literackich i ich tzw. przekładów, a nie tekstów „,codziennych” lub specjalistycznych. 
4.

To ta ocena ówczesnego stanu odnośnej wiedzy spowodowała zarówno, że zrazu zaakceptowałem wspomniany wyżej tradycyjny sposób tworzenia programów wyższego, w tym uniwersyteckiego, kształcenia specjalistów; jak i, że poczułem się wręcz zobowiązany do natychmiastowego podjęcia stosownych rozważań (meta)naukowych. Inaczej mówiąc: uruchamiając kształcenie tłumaczy na podstawie programu wytworzonego głównie na bazie intuicji doświadczonych tłumaczy, traktowałem to rozwiązanie zleconego mi zadania jako tymczasowe, a nie finalne, które trzeba będzie koniecznie doskonalić w miarę pozyskiwania odpowiedniej wiedzy naukowej.

Mówiąc krótko: na poziomie namysłu nad zastaną i obserwowaną, a także nad współtworzoną przeze mnie (uniwersytecką) praktyką edukacyjną, w żadnej mierze nie porzuciłem ani wówczas, ani później przekonania o tym, że o kształceniu z prawdziwego zdarzenia akademickim (jako pewnym specyficznym rodzaju kształcenia wyższego) jakichkolwiek specjalistów można zasadnie mówić tylko o tyle, o ile dane kształcenie jest dokonywane na podstawie programów wyprowadzonych z naukowo pozyskanej wiedzy o specyficznych właściwościach i aktywnościach kształconych specjalistów; dodam, że nie zmieniło się też moje zdanie co do tego, że tak jak wówczas, jak też aktualnie o zdecydowanej większości realizowanych w naszych uniwersytetach tzw. kierunkach kształcenia nie sposób zasadnie powiedzieć, że są one realizowane na podstawie programów kształcenia prawdziwie akademickiego.

Inna sprawa, że w dużej mierze działo się tak i nadal dzieje z powodu niezwykłej żywotności wiary naszych decydentów, ale też sporej części naszego świata akademickiego, w konieczność podtrzymywania nader szczegółowego „centralizmu edukacyjnego". Choć gołym okiem widać, że postępowanie to ma znamiona paradoksu, a nawet swoistego absurdu, nasi edukacyjni decydenci notorycznie nie dowierzają nawet najwyższej rangi specjalistom, że potrafią sami wygenerować odpowiednie programy ,wyższego kształcenia”.

Jeszcze bardziej dziwi fakt, że ani „decydenccy”, ani uniwersyteccy zwolennicy owego ,edukacyjnego centralizmu” nie dostrzegają, iż odgórne narzucanie podmiotom uczelni, wydziałów, instytutów czy katedr zbyt szczegółowych ram programowych i/lub procedur tzw. zatwierdzania jakichkolwiek edukacyjnych zmian w sposób wręcz programowy zniechęca te podmioty do poszukiwania jakichkolwiek istotnych edukacyjnych innowacji. Więcej powiem na ten temat przy innej okazji. Dziś dopowiem jedynie, że w moim przekonaniu również fakt, iż w poszczególnych uczelniach można uprawiać jakiekolwiek specjalistyczne kształcenie tylko na podstawie ramowych programów (tzw.) ,centralnie zatwierdzonych” kierunków studiów w poważnej mierze blokuje zarówno procesy naukowego różnicowania specjalistycznego kształcenia, jak i procesy naukowego fundowania wyróżnionych działów tegoż kształcenia. 
5.

Wymieniona rozprawa Zagadnienia translatoryki nie jest moją jedyną publikacją poświęconą tym zagadnieniom. W latach późniejszych napisałem jeszcze i opublikowałem kilka innych. Niektóre z nich poświeciłem specjalnie rozważeniu sprawy naukowego konstytuowania lub fundowania działalności, którą można by zasadnie nazwać ,uniwersyteckim kształceniem tłumaczy z prawdziwego zdarzenia”. Ale każdą z moich wcześniej opublikowanych prac translatorycznych trzeba traktować jako prezentującą ,tylko" wyniki osiągnięte przeze mnie w pewnym momencie realizacji programu intelektualnych działań, który sformułowałem po uruchomieniu wspomnianego wyżej wyższego kształcenia tłumaczy. Inaczej mówiąc: każda z nich znamionuje jedynie pewne ogniwo (pewien etap) rozwoju mojego translatorycznego namysłu, a nie finalny stan wyników tegoż namysłu. W skrócie można najważniejsze współczynniki programu tego namysłu zrekonstruować w postaci następujących punktów:

Po pierwsze, pragnąc zrealizować cel wyróżniony za pomocą wyrażenia ,wytworzenie prawdziwie akademickiego programu kształcenia" tego rodzaju specjalistów, jak: nauczyciele języków obcych i/lub tłumacze/translatorzy albo pośrednicy komunikacyjni, trzeba najpierw wytworzyć lub wzbogacić zasoby naukowej wiedzy, bez której nie sposób sformułować analitycznie uzasadnionej odpowiedzi na pytanie o istotę tego, co wyróżnia się (odpowiednio) za pomocą takich nazw, jak: uczenie się języków obcych, nauczanie języków obcych, nauczyciele języków obcych lub tłumaczenie, translacja, tłumacze czy translatorzy albo pośrednicy komunikacyjni.

Po drugie, chcąc umożliwić badaczom zainteresowanym tymi zagadnieniami zajęcie się w sposób profesjonalny i systematyczny tworzeniem lub pomnażaniem zasobów specjalistycznej wiedzy wymienionej w pierwszym punkcie, trzeba najpierw możliwie wyraźnie i dokładnie ukonstytuować odpowiednią dziedzinę pracy poznawczej (wytworzyć jej projekt), a następnie doprowadzić do jej instytucjonalizacji - uzyskać zgodę na utworzenie odpowiednich odrębnych akademickich instytucji, których istnienie winno umożliwić rozpoczęcie lub przyśpieszenie procesu profesjonalizacji wykonywania pracy przewidzianej w projekcie tej dziedziny.

Po trzecie, pragnąc uzyskać dla projektowanej dziedziny pracy poznawczej prawo do miana dziedziny nauki trzeba w pierwszej kolejności możliwie wyraźnie i dokładnie wyróżnić jej przedmiot, czyli zbiór obiektów i właściwości tychże, których poznawaniem mają się zająć jej podmioty i przedstawić (opisać) go w sposób spełniający odpowiednie kryteria (meta)naukowe; a następnie określić zadania poznawcze jej podmiotów. Poza tym trzeba projektowaną dziedzinę uniwersytecką wyróżnić językowo (nazwać), zwłaszcza jeśli stanowi ona pewne novum.

W konsekwencji tego rozumowania uznałem, że - chcąc nie chcąc - trzeba w pierwszej kolejności zająć się „(wy)tworzeniem” i przedstawieniem możliwie dokładnego projektu uniwersyteckiej dziedziny, której podmioty byłyby zobowiązane i zdolne do wytwarzania lub wzbogacania wspomnianego zasobu wiedzy specjalistycznej; że - inaczej mówiąc - w pierwszej kolejności trzeba się zająć konstytuowaniem dziedziny, której podmioty miałyby za zadanie przede wszystkim systematyczne naukowe badanie (poznawanie) tego, co wyróżnia się za pomocą takich 
nazw, jak: tłumaczenie, translacja, tłumacze czy translatorzy albo pośrednicy komunikacyjni.

6.

Podkreślam: to dla językowo wygodnego wyróżniania akademickiej dziedziny, której podmioty postanowiły lub mają obowiązek zajmować systematycznym rozważaniem zagadnień wymienionych w poprzedniej części zaproponowałem nazwę „translatoryka”. Dodam, że dla (również wygodnego) wyróżniania dziedziny, której podmioty winny zajmować się systematycznym (naukowym) badaniem tego, co wyróżnia się za pomocą takich nazw, jak: uczenie się języków obcych, nauczanie języków obcych, nauczyciele języków obcych, nieco wcześniej wykorzystałem nazwę ,glottodydaktyka”.

Projekt każdej z tych dziedzin stanowił w momencie jego formułowania i przedstawiania pewne novum koncepcyjne, a w jeszcze większej mierze pewne novum instytucjonalne. Nikt wcześniej nie przedstawił bowiem żadnego tego rodzaju projektu tych dziedzin; w każdym razie żadna z nich nie miała wówczas żadnej choćby tylko „nazewniczej” instytucjonalnej reprezentacji w obrębie żadnego uniwersytetu. Dodam również, że w Polsce specjaliści wyróżniani za pomocą nazwy tłumacze nie byli wówczas traktowani jako reprezentanci jakiegoś odrębnego zawodu, lecz w najlepszym razie jako reprezentanci pewnego rodzaju sztuki - pewnego ubocznego czy dodatkowego zajęcia literatów. W ówczesnych oficjalnych spisach zawodów tłumacze byli systematycznie ignorowani.

W żadnym razie nazwy ,translatoryka” nie wprowadziłem do mojego specjalistycznego języka po to tylko, by zastąpić nią nazwy wcześniej wprowadzone dla wyróżnienia namysłu nad tłumaczeniem i/lub rezultatów tego namysłu i w ten sposób „nacechować” moje odnośne teksty oryginalnością. Nie skorzystałem z żadnej wcześniej wytworzonej odnośnej nazwy z istotnych merytorycznych powodów między innymi dlatego, ponieważ wszystkie nazwy typu ,teoria tłumaczeń”, „translatologia” czy „traduktologia” były (i nadal są) nazwami wyróżniającymi zdecydowanie inne desygnaty i/lub denotaty niż te, o których (leksykalne) wyróżnienie mi chodziło; podkreślam: wszystkie wymienione nazwy zostały „wytworzone” dla wyróżniania innych zakresów pracy niż te, które ja pragnąłem wówczas językowo wyróżnić.

Najważniejszy powód, z uwagi na który musiałem wytworzyć nową nazwę dla wyróżniania konstytuowanej przeze mnie dziedziny akademickiej pracy stanowił fakt, że (obligatoryjnym) zadaniem jej podmiotów uczyniłem nie tylko realizowanie wymienionych wyżej rodzajów pracy poznawczej (w tym naukowej), lecz także wykonywanie pewnego zakresu (akademickiej) pracy edukacyjnej. Translatorykę potraktowałem wówczas i nadal traktuję tak samo jak z reguły traktuje się wszelkie akademickie dziedziny wyróżniane za pomocą nazw typu: filologia angielska, filologia romańska itd., czyli zarazem jako pewną dziedzinę (przynajmniej z założenia) nauki i jako pewną dziedzinę wyższego kształcenia. 
7.

Nie wdając się w szczegóły powiem, że z istotnych powodów nie mogłem skorzystać (i nie skorzystałem) z nazw typu: ,teoria tłumaczenia”, „nauka o thumaczeniach”, „translatologia” czy ,traduktologia” nawet dla wyróżniania samej tylko (projektowanej wówczas) translatoryki jako pewnej dziedziny pracy poznawczej. Przede wszystkim nie mogłem i nie uczyniłem tego:

- z powodu znaczeń członów tych nazw ograniczających zakres zadań poznawczych podmiotów wyróżnionych za ich pomocą dziedzin do pozyskiwania lub wzbogacania ,tylko" wiedzy o tym, co wyróżnia się za pomocą takich nazw, jak „tłumaczenie” lub „translacja”;

- z powodu znaczenia współczynników niektórych z tych nazw typu „logia” lub ,nauka”: znaczenia tych współczynników sugerują bowiem, jakoby wszelkie rozważania lub analizy realizowane albo publikowane pod ich szyldami miały charakter rozważań, analiz lub publikacji naukowych, a nawet więcej: jakoby obowiązkowo należało je jako takie traktować. A tak nigdy nie było i nadal nie jest;

- ponieważ konstruowanie bądź ,wymyślanie” jakiejś teorii ttumaczenia nigdy nie było i nie jest jedynym (ani nawet głównym) zadaniem dziedziny, której systematycznym wykonywaniem winny się zająć podmioty projektowanej przeze mnie dziedziny pracy poznawczej o nazwie „translatoryka”;

- ponieważ bezzasadne jest opatrywanie atrybutem ,naukowe” rozważań czy analiz dotyczących tłumaczenia/translacji lub ich rezultatów tylko dlatego, że dotyczą one tego rodzaju rzeczy jak tłumaczenie, języki czy literatura, lub tylko dlatego, że są wykonywane lub zostały wykonane przez kogoś zatrudnionego w jakiejś akademickiej instytucji.

Podkreślam: od samego początku projektowałem i konstytuowałem poznawczą translatorykę jako dziedzinę, której podmioty winny się ,zawodowo" zajmować pozyskiwaniem (a) nie tylko odpowiedniej wiedzy teoretycznej, lecz także, a nawet w pierwszej kolejności, odpowiedniej wiedzy empirycznej; (b) nie tylko odpowiedniej wiedzy diagnostycznej, lecz także odpowiedniej wiedzy prognostycznej, w tym przede wszystkim odpowiedniej wiedzy aplikatywnej; (c) nie tylko wiedzy o tym, co nazywa się tłumaczeniem, lecz także o tym, co nazywa się kształceniem tłumaczy, w tym pozyskiwaniem wiedzy, za pomocą której można naukowo ufundować „prawdziwie” akademickie kształcenie tłumaczy.

Jednakże na początku zajmowania się konstytuowaniem translatoryki w ogóle nie potrafiłem jeszcze w sposób wystarczająco wyrazisty zinterpretować ani związków/różnic pomiędzy translatoryką rozumianą jako pewien zakres pracy poznawczej oraz translatoryką rozumianą jako pewien zakres akademickiej pracy edukacyjnej, ani związków/różnic pomiędzy translatoryką rozumianą jako dziedzina poznawania tego, co się nazywało/nazywa „thumaczeniem”/,translacją”, oraz „translatoryką” rozumianą jako dziedzina poznawania tego, co się (kolektywnie) nazywa kształceniem tłumaczy. Było tak, ponieważ wówczas nie dysponowałem jeszcze (specjalistyczną) wiedzą, którą trzeba posiadać, by móc wszystkie te parcjalne rozumienia translatoryki wyraźnie odróżnić i zachodzące między nimi związki poprawnie odwzorować. 
Ale niezależnie od tego, z jakich powodów tak się stało, przyznać muszę, że treść pracy z 1976 roku zaświadcza, iż w czasie jej pisania jeszcze nie dysponowałem wiedzą, która umożliwiłaby mi wystarczająco wyraźnie oddzielić: ani (a) translatoryki poznawczej (rozumianej jako pewna dziedzina pracy poznawczej) od translatoryki edukacyjnej (rozumianej jako pewna dziedzina pracy edukacyjnej); ani (b) części translatoryki poznawczej, której podmioty winny się zajmować głównie poznawaniem thumaczenia/translacji, od części translatoryki poznawczej, której podmioty winny się zajmować głównie poznawaniem (i ewentualnie także naukowym projektowaniem) kształcenia tłumaczy.

\section{8.}

Gdy pisałem tamtą rozprawę, nie rozumiałem też jeszcze do końca ani związków i różnic między pracą poznawczą wykonywaną w celu pozyskania odpowiedniej wiedzy diagnostycznej oraz pracą poznawczą wykonywaną w celu pozyskania odpowiedniej wiedzy prognostycznej, ani warunków, od spełnienia których zależy możliwość ,zaliczenia” dowolnej wiedzy aplikatywnej do zbioru naukowej wiedzy aplikatywnej. Dokładnemu rozważeniu poddałem te kwestie nieco później, a sumę rezultatów odnośnych analiz przedstawiłem dopiero w monografii Zagadnienia metalingwistyki. Lingwistyka - jej przedmiot, lingwistyka stosowana ${ }^{3}$, która ukazała się w 1983 roku. Stwierdzenie, że niektórych kwestii jeszcze nie udało mi się w omawianych pracach przedstawić w sposób wystarczająco wyrazisty, nie oznacza jednak, że przedstawiłem je w nich w sposób całkiem niewłaściwy. Jako zdecydowanie mylny traktuję tylko wyrażony w końcowej części pracy z 1976 roku pogląd, jakoby dydaktykę translatoryczną należało potraktować jako pewien dział glottodydaktyki, a nie translatoryki (dodam: sensu largo).

Że jest on obarczony istotnymi mankamentami spostrzegałem niebawem. W każdym razie: już wkrótce po jego ogłoszeniu zaczęły się mnożyć moje wątpliwości co do jego zasadności. To z tego powodu pogląd ten zignorowałem zarówno w pracy powstałej w 1982 roku, jak i w pracach wówczas napisanych specjalnie na temat dydaktyki translatorycznej ${ }^{4}$. Już w pracy powstałej w 1982 roku prezentuję translatorykę (choć, powtórzę, jeszcze nie w sposób całkiem wyraźny) jako dziedzinę, do której obowiązków należy (trzeba zaliczyć) systematyczne poznawanie (wyróżnianie, ustalanie) specyficznych aktywności i właściwości nie tylko tłumaczy (translatorów), lecz także akademickich nauczycieli zajmujących się kształceniem tych pierwszych.

Mówiąc krótko: poza uwagą w sprawie dziedzinowej przynależności translatorycznej dydaktyki żaden $\mathrm{z}$ pozostałych istotnych cząstkowych poglądów wyrażonych za pomocą moich odnośnych publikacji nie stracił, moim zdaniem, swej aktualności. W sensie pewnego usprawiedliwienia wymienionej pomyłki dodam, że doszło do niej, jak sądzę, z tego powodu, że głównym celem, dla spełnienia którego napisałem odnośną pracę nie było wyjaśnienie ogólnego zbioru znaczeń nazwy

${ }^{3}$ Zob. F. Grucza (2017b).
${ }^{4}$ Zob. F. Grucza (2017c).

Applied Linguistics Papers: www.alp.uw.edu.pl 
translatoryka, lecz przedstawienie wygenerowanego do momentu jej napisania, czyli do roku 1976 roku, projektu translatoryki jako pewnej (uniwersyteckiej) dziedziny pracy poznawczej, a zwłaszcza możliwie wyraźne wyróżnienie przedmiotu, którego poznawaniem winny się zająć podmioty tej dziedziny w pierwszej kolejności. Wysunąłem ten problem na plan pierwszy tej pracy, ponieważ wyodrębniony przeze mnie przedmiot translatoryki badań nazywanych „badaniami dotyczącymi thumaczenia" został ukonstytuowany w sposób zdecydowanie inny niż czynili to autorzy prac publikowanych wówczas pod takimi szyldami jak „teoria tłumaczenia” itd.

\section{9.}

Również głównym celem, dla spełnienia którego napisałem w 1982 roku pracę Lingwistyka, lingwistyka stosowana, glottodydaktyka, translatoryka (wydaną dopiero w roku 1985), nie było wyjaśnienie kwestii znaczeń nazwy translatoryka. Jej głównym celem było ,jeszcze dokładniejsze" wykazanie tego, co łączy i co dzieli translatorykę, glottodydaktykę i lingwistykę stosowaną poprzez jeszcze dokładniejsze wyróżnienie ich przedmiotów i bardziej precyzyjny opis tychże. Nie wdając się w szczegóły można powiedzieć, że praca z roku 1985 z roku prezentuje wyniki mojej pierwszej próby doprecyzowania i zarazem uzupełnienia przedstawionej w 1976 roku odpowiedzi na pytanie o przedmiot i zadania translatoryki - próby wykonanej za pomocą kognitywnych narzędzi obszernie przedstawionych w wymienionej wyżej monografii Zagadnienia metalingwistyki.

Moje poglądy i/lub koncepcje, dotyczące zarówno glottodydaktyki, jak i translatoryki oraz poglądy przedstawione w owej monografii, formowały się na zasadzie czy w efekcie swoistych intelektualnych sprzężeń zwrotnych. W każdym razie nie było tylko tak, że rozwijałem moje translatoryczne i/lub glottodydaktyczne myśli wskutek ,przeniesienia” na grunt tych rozważań instrumentów intelektualnych powstałych w konsekwencji moich rozważań metanaukowych i/lub metalingwistycznych. Owo „przenoszenie” dokonywało się także w odwrotnym kierunku: wymieniona monografia nie powstałaby, gdyby nie to, że rozważania, których pierwsze rezultaty przedstawiłem w 1976 roku, w sposób zdecydowany wzmocniły moje (,nabyte” kilka lat wcześniej w związku $\mathrm{z}$ namysłem nad problemem związków/różnic pomiędzy lingwistyką stosowaną i glottodydaktyką) przekonanie, że ani problemów dotyczących thumaczenia/translacji, ani problemów dotyczących naukowego fundowania kształcenia tłumaczy (i/lub nauczycieli języków obcych) i wszczętego w tym związku namysłu nad pytaniem o przedmiot i zadania translatoryki nie da się należycie rozwiązać/ wykonać bez uprzedniego (a) wypełnienia luk istniejących (stwierdzonych) w zakresie stojącej wówczas do dyspozycji wiedzy metanaukowej i/lub metadydaktycznej oraz (b) wygenerowania odpowiednich kognitywnych instrumentów, w tym przede wszystkim odpowiedniego (analitycznie wytworzonego) specjalistycznego języka.

Jako w zupełności aktualne traktuję przed wszystkim najważniejsze elementy sporządzonych przeze mnie wówczas opisów ogólnego przedmiotu i głównych za-

${ }^{5}$ Zob. F. Grucza (2017d). 
dań translatoryki rozumianej jako pewna dziedzina pracy poznawczej. Jako nadal aktualne, bo dotąd niezrealizowane w wystarczającej mierze, traktuję też wszystkie generalne zadania wyznaczone wówczas podmiotom translatoryki (sensu largo), a w szczególności ich obowiązek systematycznego zmierzania do stopniowego przekształcania translatoryki w dziedzinę zdolną do dostarczania naukowo uzasadnionej aplikatywnej wiedzy - w tym wiedzy, koniecznie potrzebnej najpierw do tego, by móc naukowo ufundować rozważania dotyczące (programów) kształcenia tłumaczy, a następnie do tego, by móc przekształcić już realizowane wyższe kształcenie tłumaczy w prawdziwie akademickie kształcenie odpowiednich specjalistów. Jako nadal zupełnie aktualny traktuję też (zasygnalizowany już wówczas) obowiązek podmiotów translatoryki systematycznego dążenia zarówno do uzyskania dla translatoryki statusu relatywnie samodzielnej dziedziny akademickiej pracy, jak i do instytucjonalnego wyodrębnienia translatoryki (sensu largo).

\section{0.}

Najważniejsze innowacyjne elementy mojego wówczas wytworzonego projektu „całości” translatoryki wymieniłem już wyżej, odpowiadając na pytanie, dlaczego dla wyróżniania tej dziedziny nie skorzystałem z nazw typu teoria tłumaczenia, lecz zaproponowałem nazwę translatoryka. Przypomnę: istotne novum tego projektu polega/ło na potraktowaniu translatoryki jako pewnej dziedziny pracy uniwersyteckiej/akademickiej, obejmującej dwie części zarazem - translatorykę poznawczą i translatorykę edukacyjną: w myśl tego projektu, podmioty translatoryki mają (choć niekoniecznie wszystkie w równej mierze) obowiązek systematycznego zajmowania się nie tylko (w miarę możności naukowym) rozważaniem/analizowaniem odpowiednich zagadnień translatorycznych, lecz także (praktycznym) wykonywaniem odpowiednich translatorycznych zadań edukacyjnych, w szczególności kształceniem tłumaczy jako „odrębnych” specjalistów, a nie jako filologów potrafiących między innymi także tłumaczyć.

Wyżej wymieniłem już też szereg innowacji pierwotnego projektu (zarysu) pierwszej części tejże dziedziny, czyli translatoryki poznawczej. Przypomnę, po pierwsze, że między innymi należy do nich uczynienie przedmiotem jej badań nie tylko tego, co nazywa się ,tłumaczeniem”, lecz także tego, co się wyróżnia jako kształcenie tłumaczy; po drugie, że inne novum tego projektu polegało/polega na tym, że zupełnie inaczej, aniżeli z reguły czyniono to wcześniej, określiłem w nim (ogólny) przedmiot badań tej części translatoryki poznawczej, o której mówi się (mówiono), że zajmuje się tłumaczeniem czy translacją. Ale jest jeszcze jedno novum tego projektu zasługujące na podkreślenie.

W skrócie można powiedzieć, że jeśli nie najważniejsza, to na pewno jedna z jego istotnych innowacji polegała na (nazwę to tak) przeniesieniu punktu ciężkości badań wyróżnianych (określanych) jako ,(poznawcze) zajmowanie się tłumaczeniem/ translacją" z tłumaczonych/przetłumaczonych tekstów na podmioty aktywności/czynności nazywanych ,tłumaczeniem” lub ,translacją”. Inaczej mówiąc: to novum „mojego” projektu translatoryki poznawczej polega na tym, że ,z góry” zobowiązuje on podmioty tej dziedziny do zajęcia się w pierwszej kolejności pozna- 
waniem (wyróżnianiem, określaniem itd.) specyficznych aktywności tłumaczy (translatorów) oraz ich specyficznych właściwości, tzn. tych ich właściwości, których posiadanie warunkuje możliwość dokonywania przez konkretne osoby aktywności nazywanych thumaczeniem lub translacją. Jeszcze inaczej mówiąc: to novum tego projektu polegało na, że tak powiem, pozbawieniu thumaczonych/przetłumaczonych tekstów statusu centralnych obiektów pracy poznawczej podmiotów pracy mającej na celu poznanie tego, co nazywa się thumaczeniem lub translacją i przyznaniu tego statusu podmiotom aktywności nazywanych thumaczeniem lub translacją, czyli konkretnym thumaczom.

Ale jako pewne novum tego projektu wypada ocenić też przedstawioną w nim próbę poddania nie tylko poznawania tłumaczenia, lecz także poznawania kształcenia tłumaczy odpowiednim rygorom/wymogom poznawania naukowego (nauki) w tym w pierwszej kolejności wymogowi, w myśl którego o naukowym wykonywaniu jakiekolwiek pracy poznawczej można zasadnie mówić tylko w tej mierze, w jakiej wykonujące ją podmioty wyraźnie określiły przedmiot swej pracy poznawczej. Jako pewne jeszcze inne novum tego projektu wypada ocenić też wyraźnie zasygnalizowane w pracy z 1982 roku istotne „wzbogacenie” ogólnego zbioru zadań podmiotów translatoryki poznawczej - zarówno zajmujących się pozyskiwaniem wiedzy o thumaczeniu, jak i zajmujących się zdobywaniem wiedzy o kształceniu thumaczy - o obowiązek systematycznego pozyskiwania nie tylko odpowiedniej wiedzy diagnostycznej, lecz (między innymi) także odpowiedniej wiedzy aplikatywnej.

\section{2.}

Dla zapobieżenia możliwym nieporozumieniom dodam na koniec tych uwag jeszcze to:

- po pierwsze, stwierdzenie, iż generalnie podtrzymuję moje ówczesne rozumienie translatoryki, nie oznacza, że pokrywa się ono całkowicie z moim aktualnym rozumieniem tej dziedziny - to ostatnie jest o wiele bogatsze;

- po drugie, że (również) moje rozumienie translatoryki stopniowo wzbogacało się przez cały czas, który minął od chwili powstania prezentowanych tu prac;

- po trzecie, że niektóre „nowe” elementy mojego rozumienia niektórych współczynników tej dziedziny przedstawiłem już w odnośnych pracach napisanych w tzw. międzyczasie;

- po czwarte, że jeśli czasu i sił starczy, przedstawię moje aktualne rozumienie translatoryki w postaci odrębnej monografii.

$\mathrm{Tu}$ powiem $\mathrm{w}$ tym związku tylko tyle: rozumienia translatoryki zarysowane $\mathrm{w}$ zamieszczonych niżej pracach udało mi się wzbogacić w konsekwencji coraz dokładniejszych, ale wykonanych nie tylko przeze mnie, lecz także przez wielu innych autorów (w jakiejś mierze podzielających moje poglądy w sprawie translatoryki), analiz nie tylko różnych współczynników tego, co wyróżnia się za pomocą nazw typu „tłumaczenie” lub „translacja”, lecz także, a być może przede wszystkim, w konsekwencji coraz dokładniejszych analiz desygnatów i/lub denotatów wyróż- 
nianych za pomocą takich nazw, jak: (a) komunikowanie się ludzi (istot żywych) w ogóle, językowe porozumiewanie się ludzi i/lub kulturowe komunikowanie/porozumiewanie się ludzi; (b) język, kultura i teksty; (c) nauka i wiedza; (d) uniwersytet, szkoła/ uczelnia (wyższa) i dziedzina pracy akademickiej.

W konsekwencji tych rozważań jako jeszcze mniej zasadne traktuję dziś nie tylko umiejscawianie translatoryki w obrębie jakiejkolwiek filologii, lecz także uznawanie jej za pewnego rodzaju ,pochodną” dziedzinę lingwistyki - zależną tylko od niej. Dziś za uzasadnione, a nawet za konieczne, traktuję uprawianie jej w obrębie pracy poznawczej, którą od pewnego czasu wyróżniam za pomocą nazwy ,komunikologia ogólna". Zarazem jako niesłuszny traktuję dziś (wyznawany przez wiele lat także przeze mnie) pogląd, w myśl którego desygnacyjne funkcje nazwy ,tekst(y)” należało z góry ograniczyć do wyróżniania odpowiednich (wy)tworów językowych.

Już od dłuższego czasu translatorykę poznawczą dzielę najpierw na dwie części - na „bazową translatoryką poznawczą” i ,metatranslatorykę”; zarówno rozważania/analizy podejmowane w celu naukowego ufundowania aktywności wyróżnianych jako zajmowanie się tłumaczeniem lub jako zajmowanie się kształceniem tłumaczy, jak i aktywności mające na celu naukowe uzasadnienie projektów odpowiednich dziedzin (zakresów) „uniwersyteckiej” pracy, czyli w skrócie: aktywności mające na celu naukowe ukonstytuowanie translatoryki i jej różnych części traktuję dziś jako zadania, których wykon(yw)anie należy do obowiązków podmiotów metatranslatoryki; ale do jej obowiązków zaliczam też wykonywanie pracy intelektualnej w celu pozyskania wiedzy potrzebnej do tego, by móc w sposób racjonalnie (analitycznie) uzasadniony odpowiedzieć na pytanie, czy, a jeśli tak, to dlaczego należy całości translatoryki przyznać najpierw status pewnej względnie samodzielnej dziedziny pracy uniwersyteckiej, a następnie prawo do odpowiedniej (również względnie) samodzielnej (odrębnej) reprezentacji instytucjonalnej.

Kończąc dopowiem, że zdaję sobie dobrze sprawę z tego, że w okresie po ukazaniu się mojej wspomnianej rozprawy Zagadnienia translatoryki napisanych i opublikowanych zostało wiele prac zarówno na temat tłumaczenia/translacji, jak i kształcenia tłumaczy, że spory udział w tym dorobku mają polscy autorzy i że pośród prac napisanych przez tych ostatnich są też pozycje znaczące, a nawet znakomite $^{6}$. Natomiast w żaden istotny sposób nie poprawił się, moim zdaniem, w tym czasie ani dziedzinowy statusu translatoryki, ani stan jej instytucjonalizacji.

Mówiąc krótko: translatoryka nie wybiła się na razie w żadnym uniwersytecie na poziom dziedzin samodzielnych, w szczególności nie uzyskała na razie statusu odrębnego kierunku studiów. Nadal jest uprawiana pod różnymi „obcymi” szyldami. A za wykształconego tłumacza nadal uznaje się absolwentów studiów filologicznych, którzy ukończyli odpowiednią „filologiczną” specjalizację. Ale bywa, że za takich nadal uznaje się też absolwentów filologicznych studiów, którzy zaliczyli jakieś seminarium lub jakiś inne uniwersyteckie zajęcia poświęcone tłumaczeniu/translacji.

${ }^{6}$ Do tego zbioru zaliczam między innymi następujące prace: K. Klimkowski (2015), M. Płużyczka (2015), J. Żmudzki (2015). 


\section{Bibliografia}

Grucza, F. (2017a), Zagadnienia Translatoryki, (w:) F. Grucza, Dzieła zebrane, t. 4: O kulturze, kulturach i kulturologii. O thumaczach, thumaczeniu i translatoryce. Pod red. S. Grucza/ M. Olpińska-Szkiełko/ M. Płużyczka/ I. Banasiak/ M. Łączek/ A. Bonek/ A. Kaleta/ A. Sztuk. Warszawa, 149-161. (URL http://www.iksi.uw.edu.pl/documents/11738337/14640936/FG_Tom_4.pdf).

Grucza, F. (2017b), Dzieta zebrane, t. 8: Zagadnienia metalingwistyki. Lingwistyka-jej przedmiot, lingwistyka stosowana. Pod red. S. Grucza/ M. Olpińska-Szkiełko/ M. Płużyczka/ I. Banasiak/ M. Łączek/ A. Bonek/ A. Kaleta/ A. Sztuk. Warszawa. (URL http://www.iksi.uw.edu.pl/documents/11738337/14640936/FG_Tom_8.pdf).

Grucza, F. (2017c), Ttumaczenie i jego funkcje glottodydaktyczne, (w:) F. Grucza, Dzieła zebrane, t. 4: O kulturze, kulturach i kulturologii. O thumaczach, thumaczeniu i translatoryce. Pod red. S. Grucza/ M. Olpińska-Szkiełko/ M. Płużyczka/ I. Banasiak/ M. Łączek/ A. Bonek/ A. Kaleta/ A. Sztuk. Warszawa, 163-176. (URL http://www.iksi.uw.edu.pl/documents/11738337/14640936/FG_Tom_4.pdf).

Grucza, F. (2017d), Lingwistyka, lingwistyka stosowana, glottodydaktyka, translatoryka, (w:) F. Grucza, Dzieła zebrane, t. 2: O nauce i naukach. O lingwistyce stosowanej. Pod red. S. Grucza/ M. Olpińska-Szkiełko/ M. Płużyczka/ I. Banasiak/ M. Łączek/ A. Bonek/ A. Kaleta/ A. Sztuk. Warszawa, 177-195.

Grucza, F. (2017e), Wyodrębnienie się, stan aktualny i perspektywy świata translacji oraz translatoryki, (w:) F. Grucza, Dzieła zebrane, t. 4: O kulturze, kulturach i kulturologii. O thumaczach, thumaczeniu i translatoryce. Pod red. S. Grucza/ M. Olpińska-Szkiełko/ M. Płużyczka/ I. Banasiak/ M. Łączek/ A. Bonek/ A. Kaleta/ A. Sztuk. Warszawa, 239-261. (URL http://www.iksi.uw.edu.pl/documents/11738337/14640936/FG_Tom_4.pdf).

Klimkowski, K. (2015), Towards a shared curriculum in translator and interpreter education. Wrocław/ Washington, D.C.

Płużyczka, M. (2015), Tłumaczenie a vista. Rozważania teoretyczne $i$ badania eyetrackingowe. Warszawa.

Żmudzki, J. (2015), Blattdolmetschen in paradigmatischer Perspektive der anthropozentrischen Translatorik. Frankfurt a. Main. 